\title{
WORKING WITH THE POET
}

\section{A TRANSLATOR'S RESPONSE}

In a world where managing the news is more urgent than trying to understand the history behind it, or the forces that shape it, comes Meir Wieseltier, all six feet, three inches of him, with his halo of silvery white hair, looking like an aging basketball player or an unbearded, misplaced prophet walking his English setter through the traffic-snarled streets of south Tel-Aviv, releasing his torrent of words for many Israelis unable to cope, punching holes in what's left of our frayed representations of love and war.

I can't stand political poetry: that civil and prophetic posturing (Why should anyone speak in broken lines?)

These lines from "Pro $\&$ Con," which was published in 1983 , call on the poet to be silent:

let the poet turn inward, let him study his navel, dream of his father and mother, or draw pigeons on the neighbor's roof a street in the city, a house on the street, a room inside the house, an orange peel on the table slowly drying

But he goes on to say

sometimes I can't control myself, and like a pervert I sneak up on the wax figures' display.

Here they are lined up in a row, these gawky masks in charge of deciding our fate 
The sight of these leaders posing "with the postures of men who get things done... smiling their smiles almost like humans" drives him, in the end, in a furious closing stanza, to incoherence.

Meir Wieseltier first brought me some of his poems to translate for the Spring 1977 issue of the Chicago journal TriQuarterly, which featured contemporary Israeli literature. It was soon after I arrived in Israel. Our friendship started in a cloud of smoke from his Gauloises cigarettes (which I managed to survive) and grew over the many years that followed. As we consulted, argued, and read his poems together, I refined my understanding and struggled to transform his Hebrew words - their sense and sound-into English (American, really) poems.

Wieseltier, who rails against "political poetry" in the poem quoted above, has written the most powerful poems of social and political protest in Israel, poems that are tragically timeless, like "Sonnet: Against Making Blood Speak Out," published in 1984:

If I die one day from the bullet of a young killer

... or in a bomb explosion while I'm checking the price

of cucumbers in the market, don't dare say

that my blood permits you to justify your wrongs.

A deeply caring part of him, along with his critical awareness, temper his fury. He is no longer the "bad boy" of the sixties (there were some wouldbe Allen Ginsbergs and dadaists in those days enlivening Tel-Aviv in smoke-filled cafes and in new little magazines, some of which Wieseltier edited), when he and a few other young poets, especially Yonah Wallach and Ya'ir Hurwitz, were exposing every human and inhuman frailty, turning traditional Hebrew poetry inside out, making the ancient Hebrew language new for their generation, as Yehuda Amichai, the most accomplished and admired poet of the preceding generation, and Natan Zach had done in their time. 
Now Wieseltier, in an age of cyberspace and terrorism and damaged hope, is the distinguished recipient of the Israel Prize, his country's highest honor, awarded on Independence Day in the millennial year 2000 in the presence of the Israeli establishment (president, prime minister, minister of education, chief justice of the Supreme Court, mayor of Jerusalem, and so on) to its most antiestablishment poet. A poet of intense engagement, historical awareness, and verbal power, he was given "the highest possible honor in Israel for his long-standing, subversive work," according to one critic at the time.

But there is more to Wieseltier than subversion. The accumulation of tragicomic detail in his poems, black humor, and visceral imagery offers no escape from the-way-it-is. His words force us to confront the absurd and seamy side of life, head-on. One of his most stunning early poems, "Isaac's Story," is about child abuse in a shabby Tel-Aviv office and was written in the early seventies, before the avalanche of such stories and poems. The sexually charged language focuses on the surroundings and pathos of the boy, who finally found a summer job when he was picked up in the steaming streets of the first modern city on the Mediterranean coast.

Wieseltier has been strongly rooted in Tel-Aviv, ever since he came to live and go to school there in 1955 , cherishing his love-hate relationship with the city, poking into its darkest corners with cool appraisal, even its unbuilt subway ("Weather," "Isaac's Story," "Skywriting," "Naive Painting," "The Man at the Piano," "The Tel-Aviv Subway"). He is equally at home in the Hebrew Bible, often using its ancient phrases as well as its characters to illuminate contemporary disasters. All his distrust of the rhetoric of religious devotion culminates in the last couplet of the final stanza of "Abraham":

Abraham didn't value a thing in the world but God.

Against Him, he never sinned, no difference between them. 
Unlike Isaac who loved his uncouth son, unlike Jacob who slaved for women, who limped from God's thrashing all night, who saw angeled ladders only in dreams. Not Abraham. He loved God and God loved him. And together they counted the righteous in the cities before wiping them out.

In making a representative selection from more than forty years of Wieseltier's poems, I discovered that my decisions about which poems to translate had been highlighting continuing themes: they were anticlerical ("A Request," "Adoshem," "Burning Holy Books"), antigovernment ("The Secret of Authority," "Garbage Dump 200o," "Pro \& Con"), antiwar, and antimilitary ("Song of the Last Soldier," "Call-Up," "Salt on the Wounds of the Land," “To Be Continued"). Some of Wieseltier's work is even antipoetry, demonstrating his profound skepticism of poetry as communication in poems such as "Take" and "Poetry Swallowed."

Wieseltier can be merciless in his polemic against state-funded orthodox religious coercion or political rot and wrongheadedness, but slyly comic at the same time. From the beginning of his career, he has converted despair and disgust into wit and irony, with hard-hitting language and a wry smile. His voice is alternately anarchic and involved, angry and caring, serious and hilarious, cacophonous and lyric. "The Soliloquy of Dada the Cat" is an exquisite rendering of that voice. Here are the first few lines:

I was scrawny as a wormy branch

going wild in trash cans, and I was a pampered pet stuffed with prime turkey to restore me, and then again I was a beloved kitty fattened with a baby bottle, and I was a neglected cat, kicked down the stairs or out into the yard, revived. 
There is more pain than bitterness in many of Wieseltier's recent poems, as in his anguish over the disastrous midair collision of two Israeli helicopters filled with seventy-three young Israeli soldiers on their way to the war in Lebanon ("On the Seventy-three"). Pain overrides rage in lines like these:

all these corpses and wounded and disabled are so real that any rhetoric is beyond them, their lives are finished their likely screams have faded somewhere in Lebanon.

Still, there is a strongly affirmative resonance beyond the sorrows and futilities in many of these poems, an enduring resonance, as in "The Flower of Anarchy," a love poem from which the title of this book is taken. Freedom, the essential spirit of anarchy, waves its banners, and even its dog's ears ("Poems with a Dog, 3"), throughout Wieseltier's work, as does freedom from State, from religion, from any apparatus or relationship that would constrict or shackle it. But apart from Bakunin, and earlier writers and philosophers, Wieseltier seems closest to the American poet Hayden Carruth, an anarchist by his own definition: "no doctrine, no ideology. . . no party line, no required procedure, no orthodoxy." These have been Wieseltier's guiding principles throughout his writing career. As Dada the cat says in the last line of his soliloquy, like God to Moses (and like Popeye too): "I am what I am."

Love is a well-explored theme here-love of memorable women, and for his mother, in the compassionate "Letter I" and "Letter 2." His work is full of zest for experience, notably in his travels, and a voracious appetite for life. He displays a lonely yet comic sense of himself as a defender of human values ("I Ask Myself") and human foolishness ("Musée Picasso"). He enjoys the influence of many poets in other languages: Apollinaire, Mallarmé, Neruda, Cavafy, Yeats, Eliot, Cummings, Pound. It is not easy to balance all this with the rage against everything wrong in our place and in our time. But has it ever been different for poetry? 
Meir Wieseltier was born in Moscow in 194I and taken in the same year by his mother with two older sisters on a half-starving trek to Novosibirsk in southwestern Siberia, when hundreds of thousands of peoplewomen, children, and the aged-were evacuated from Moscow because of the war. He never knew his father, who was killed as a soldier in the Soviet Army in Leningrad. After the war and the wandering with his family as a DP through Poland, Germany, and France, he arrived in Israel in 1949, the first year of the newly declared State. A bittersweet nostalgia for his preteen years, uncorrupted by symbols of nationalistic fervor, in the small town of Netanya, is lyrically caught in "Far from the Flag Parade," included in his latest book:

It was sweet, dark, and tangy

under the heavy branches

of the citrus trees bent

around Ein-Hatkehelt and Avikhail.

I called it homeland.

Shade streaming from the trees,

the heavy heads of the Shamutti oranges

scattered around me,

a glowing, saturated yours-for-the-taking,

far from the flag parade,

I called it homeland.

That was a long time ago. A kind of piratical act

of a boy who found

something he wasn't looking for.

This is the first book-length collection of Meir Wieseltier's poetry in English. In Hebrew he is a master of word games, extended metaphor, alliteration, onomatopoeia, and rhyme, often juxtaposing biblical archaic Hebrew with the colloquial. Every translator of Hebrew poetry faces the impossible task of transferring the freshness, the emotional precision, 
the poetic skill, the layering of meaning in the Hebrew words and the three root letters that make up the words, into another language-into poetry, with the original passion and meaning. The music.

I have been especially fortunate to work with the poet himself in the making of this book, and to listen to his voice. I am grateful for his poems, and for his invaluable help in bringing them into English.

Shirley Kaufman Jerusalem, 2003 
This page intentionally left blank 